\title{
Cholesterol-rich diet induced improvement of hemodynamic system indices in SHR
}

\author{
G.V. Portnichenko, S.V. Goncharov, D.O. Stroy, V.E. Dosenko \\ Bogomoletz Institute of Physiology,NAS of Ukraine; email: krissaegrim1@gmail.com
}

\begin{abstract}
Metabolic syndrome is the nowadays problem that arose as a result of changes in lifestyle and diet. Several of the key factors of this disorder are lipid metabolism disturbances and hypertension. However, there is little known about combined influence of this factors and their contribution to the functional changes. This work is aimed to elucidate the effects of cholesterol-rich diet on major hemodynamic indices and lipid metabolism in SHR rats. The experiments were performed in 6-month old Wistar and SHR rats. Animals were fed for 8 weeks with enriched by cholesterol ( $3 \% \mathrm{w} / \mathrm{w}$, Sigma) standard rodent rations. Cardiohemodynamics measured in vivo by Pressure-sensitive microcatheter $2 F$ ("Millar Instruments", USA) introduced into left ventricle. Blood cholesterol profile was measured biochemically. The obtained data, paradoxically, signified that unlike the Wistar rats in SHR the major heart function parameters like Ejection fraction (31\% increase), Stroke Volume ( $72 \%$ increase), Cardiac Output (69\% increase) etc. improved after cholesterol diet. And at the same time SHR were more resistant to changes in blood lipid composition - they kept the same level of $H D L$ and reached $46 \%$ lower $L D L$ level than Wistar rats. Thus, chronic arterial hypertension reduces the sensitivity of rats to exogenous cholesterol. Combined influence of cholesterol and hypertension protects heart function in comparison to normotensive rats.
\end{abstract}

Key words: hypertension; lipid metabolism; cholesterol diet; cardiohemodynamics; spontaneously hypertensive rats.

\section{INTRODUCTION}

Many researches are indicating the great value of lipid metabolism in the field of heart pathophysiology, particularly, in cardiac failure development [1-4]. AKT/PI3K pathway is involved in high cholesterol response of the heart cells [5], and this is one of the main metabolic pathways responsible for cardiac growth, in particular hypertrophic [6]. Hypertrophy in turn is the main adaptive response of the heart to increased afterload, which can be caused by hypertension. Ho-Jin Park and colleagues [1] showed a link between lipid metabolism and parasympathetic response in chicken atrial myocytes and mouse heart that may affect normal functioning of the heart, and provide possible connection to cardiac arrhythmias development. The rhythm disorders are known to be concomitant to hypertensioninduced hypertrophy $[7,8]$. Also there is a connection between hypertension and lipid dis- orders/obesity in pathological condition known as metabolic syndrome, and these factors are pivotal in its development [9]. The purpose of our work was to investigate the combined influence of cholesterol and hypertension on hemodynamic system function and lipid metabolism.

\section{METHODS}

Animal model and experimental design

The experiments were performed in 6-month old Wistar and spontaneously hypertensive (SHR) rats. In order to induce atherogenesis, the animals were fed for 8 weeks with standard rodent rations enriched by cholesterol (3\% $\mathrm{w} / \mathrm{w}$, «Sigma»,USA). The rats were divided in 4 experimental groups: 1) Wistar rats $(\mathrm{n}=16$, standard diet, weight $294 \pm 22 \mathrm{~g}$ ), 2) Wistar rats $(\mathrm{n}=16,3 \%$ cholesterol diet, weight $288 \pm 78 \mathrm{~g}$ ), 3) SHR ( $\mathrm{n}=12$, standard diet, weight $293 \pm 43 \mathrm{~g}$ ), 4) SHR ( $\mathrm{n}=16,3 \%$ cholesterol diet, $328 \pm 50 \mathrm{~g})$.

(C) G.V. Portnichenko, S.V. Goncharov, D.O. Stroy, V.E. Dosenko 
All SHR were previously tested and assured for their hypertensive state (arterial pressure over $150 \mathrm{~mm} \mathrm{Hg}$ ). This procedure was performed using sphygmomanometer ("HSE", Germany). Rats were carefully placed in the cylindrical box in the way to leave their tails exposed for examination. The pressure measurement was conducted in resting state of animals.

\section{Hemodynamic parameters examination}

Heart function indices were acquired from rats, narcotized by urethane $(1.5 \mathrm{~g} / \mathrm{kg})$. Pressure-sensitive microcatheter 2F ("Millar Instruments", USA) [10] was introduced to left ventricle of the heart through the dissected left common carotid artery. After that, using provided software from Millar Instruments, the heart P-V loops were registered and analyzed. In order to obtain myocardium elasticity data, some occlusions of vena cava inferior were performed through the little incision below the metasternum. The occlusion data were acquired during direct short term squeezing of vena cava inferior and subsequent lowering of blood flow in the heart. Using provided software, a list of hemodynamic parameters was acquired: heart rate, end-systolic pressure, end-diastolic pressure, end-systolic volume of left ventricle, end-diastolic volume of left ventricle, stroke volume, cardiac output, $\mathrm{dp} / \mathrm{dt} \max$ and min, time constant for isovolumic relaxation (Tau), acquired by Weiss method (1976) etc. Effective arterial elastance was calculated as a ratio of end-systolic pressure to strike volume [7]. Pressure-volume interrelations were analyzed using PVAN 3.6 software ("Millar Instruments", USA). Conventional volume units from raw data were converted to volume units $(\mu 1)$ using calibration equation (slope 20.25X RVU-intercept 29.05). For calibration purposes, the catheter was immersed in calibration cuvette with several known diameter and volume cylindrical holes. Cuvette was filled with heparin stabilized rat blood.

\section{Blood lipid profile determination}

Concentration of cholesterol, triglycerides, lipoproteins of high, low and very low density were investigated in rat blood using biochemical analyzer Bio System A25 ("Bio-Systems" S.A., Spain). Atherogenic index was calculated by the next equation (TC-HDL)/HDL.

\section{Statistical analysis}

Statistical significance of differences between experimental groups (pretested by Levenes test for homoscedasticity, and by KolmogorovaSmirnova normality test) was tested by ANOVA with post-hoc multiple comparisons using Games-Howell test.

\section{RESULTS AND DISCUSSION}

The hypothesis behind this work was that the cholesterol-rich diet was expected to worsen hemodynamic indices in Wistar rats and especially in SHR as they already have pathological process at work. Indeed, the cholesterol-rich diet changed the pumping function of the heart of Wistar rats in comparison to standard diet by a number of indices (Fig. 1, 2, Table): stroke volume (20\% decrease), ejection fraction (1\% increase), cardiac output (33\% decrease), stroke work (13\% decrease), maximal power (23\% decrease).

However, the pumping function of the heart of SHR rats with cholesterol-rich diet was changed in a different way by some indices (Fig. 1, 2, Table): stroke volume (72\% increase), ejection fraction (31\% increase), cardiac output (69\% increase), stroke work (77\% increase), maximal power (59\% increase).

Systolic function was evaluated by the next set of indices, describing difference between Wistar rats on cholesterol-rich versus standard diet (Fig. 3, Table): heart rate (11\% decrease), end-systolic volume (33\% decrease), end-systolic pressure (34\% increase), maximal speed of pressure change $\mathrm{dP} / \mathrm{dt} \max (22 \%$ decrease), end-systolic maximum volume elasticity (Emax) (99\% increase), maximal speed of volume change $\mathrm{dV} / \mathrm{dt} \max (36 \%$ decrease), volume at the point of maximal speed of pressure change (30\% 

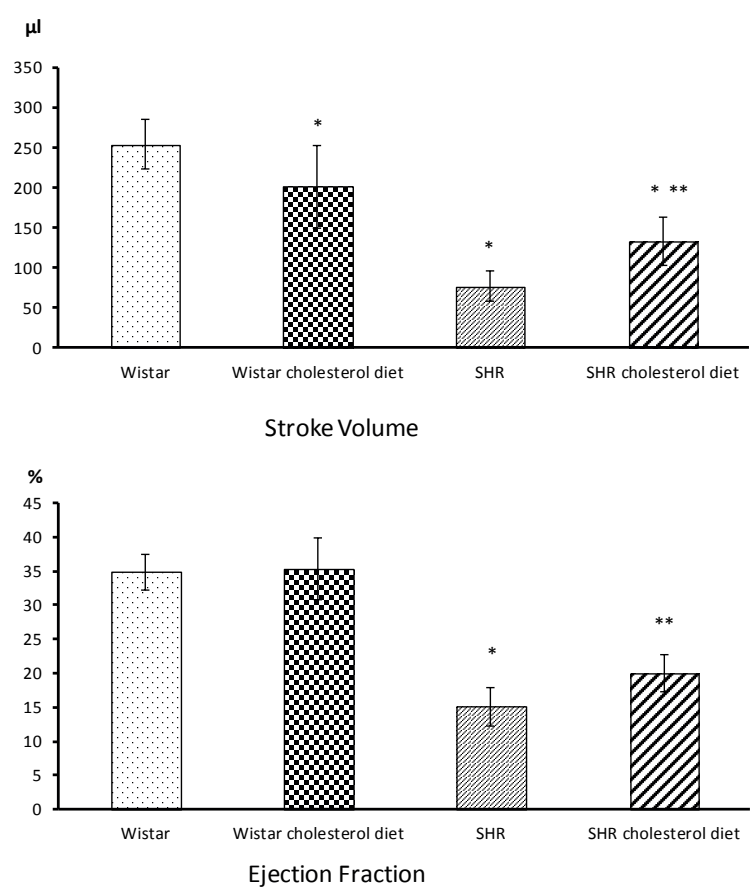

Fig. 1. Effect of cholesterol diet (3\%) on stroke volume and ejection fraction parameters of Wistar and SHR rats. * statistically significant difference comparing to Wistar rats on standard $\operatorname{diet}(\mathrm{P}<0.05)$

** statistically significant difference comparing to SHR on standard $\operatorname{diet}(\mathrm{P}<0.05)$
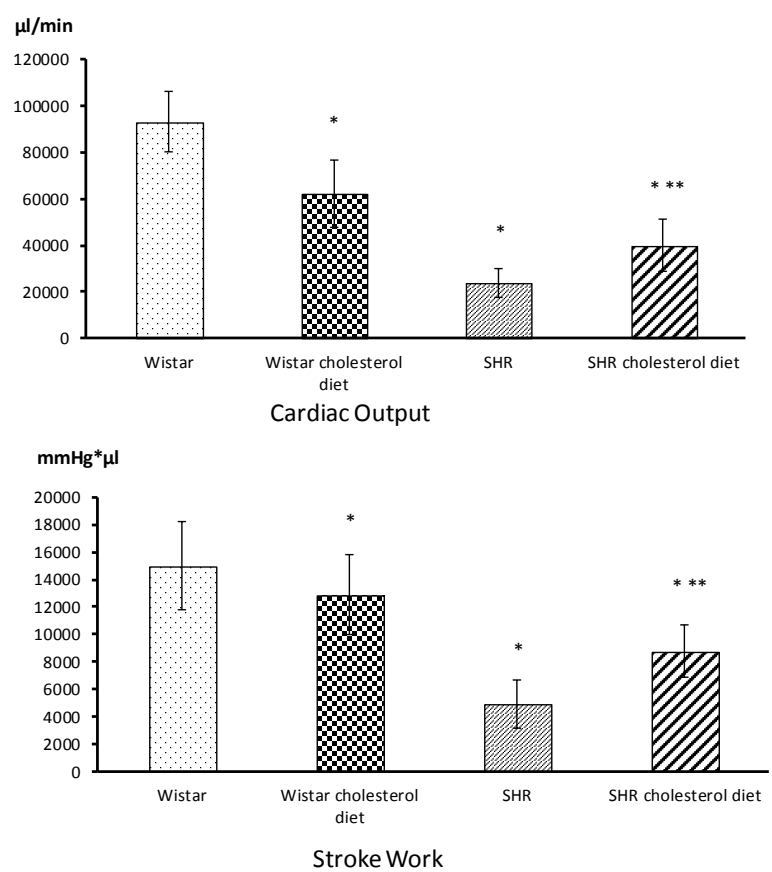

Fig. 2. Effect of cholesterol diet (3\%) on cardiac output and stroke work of Wistar and SHR rats.

* statistically significant difference comparing to Wistar rats on standard $\operatorname{diet}(\mathrm{P}<0.05)$

** statistically significant difference comparing to SHR on standard $\operatorname{diet}(\mathrm{P}<0.05)$ 
Cardiohemodynamic parameters of Wistar rats and SHR while on standard or cholesterol diet (M \pm SE).

\begin{tabular}{|c|c|c|c|c|}
\hline Parameter & Wistar & $\begin{array}{c}\text { Wistar } \\
\text { cholesterol diet }\end{array}$ & SHR & $\begin{array}{c}\text { SHR } \\
\text { cholesterol diet }\end{array}$ \\
\hline Heart rate, bpm & $363.4 \pm 18.1$ & $320.4 \pm 17.8^{*}$ & $308.6 \pm 10.4^{*}$ & $288.2 \pm 14.7 * * *$ \\
\hline End-systolic volume, $\mu \mathrm{L}$ & $493.9 \pm 37.9$ & $329.6 \pm 18.6^{*}$ & $434.3 \pm 58.2 *$ & $530.4 \pm 64.05 * * *$ \\
\hline End-diastolic volume, $\mu \mathrm{L}$ & $682.4 \pm 40.9$ & $493.1 \pm 65.7^{*}$ & $460.4 \pm 45.9^{*}$ & $614.4 \pm 75.2 * * *$ \\
\hline End-diastolic pressure, $\mathrm{mmHg}$ & $1.3 \pm 1.7$ & $2.6 \pm 1.7^{*}$ & $5.7 \pm 2.7^{*}$ & $5.2 \pm 1.1 *$ \\
\hline $\mathrm{dP} / \mathrm{dt}_{\max }, \mathrm{mmHg} / \mathrm{s}$ & $9337.3 \pm 855.9$ & $11484.2 \pm 464.5^{*}$ & $7169.5 \pm 314.2 *$ & $6524.3 \pm 1046.3 * * *$ \\
\hline $\mathrm{dP} / \mathrm{dt}_{\min }, \mathrm{mmHg} / \mathrm{s}$ & $-9221.5 \pm 981.1$ & $-6579.6 \pm 806^{*}$ & $-6810.9 \pm 315.2^{*}$ & $-6353.9 \pm 962.2 * * *$ \\
\hline Tau_w, ms & $7.8 \pm 0.4$ & $9.6 \pm 1.4^{*}$ & $10.08 \pm 1.02 *$ & $10.6 \pm 0.8 * * *$ \\
\hline
\end{tabular}

* statistically significant difference comparing to Wistar on standard diet $(\mathrm{P}<0.05)$

** statistically significant difference comparing to SHR on standard diet $(\mathrm{P}<0.05)$.

decrease). Systolic function indices describing SHR rats with cholesterol-rich versus standard diet difference: heart rate ( $6 \%$ decrease), endsystolic volume ( $22 \%$ increase), end-systolic pressure (13\% decrease), maximal speed of pressure change $\mathrm{dP} / \mathrm{dt} \max (9 \%$ decrease), endsystolic left ventricular maximum volume elasticity (Emax) (37\% decrease), maximal speed of volume change $\mathrm{dV} / \mathrm{dt} \max (74 \%$ increase), volume at the point of maximal speed of pres-
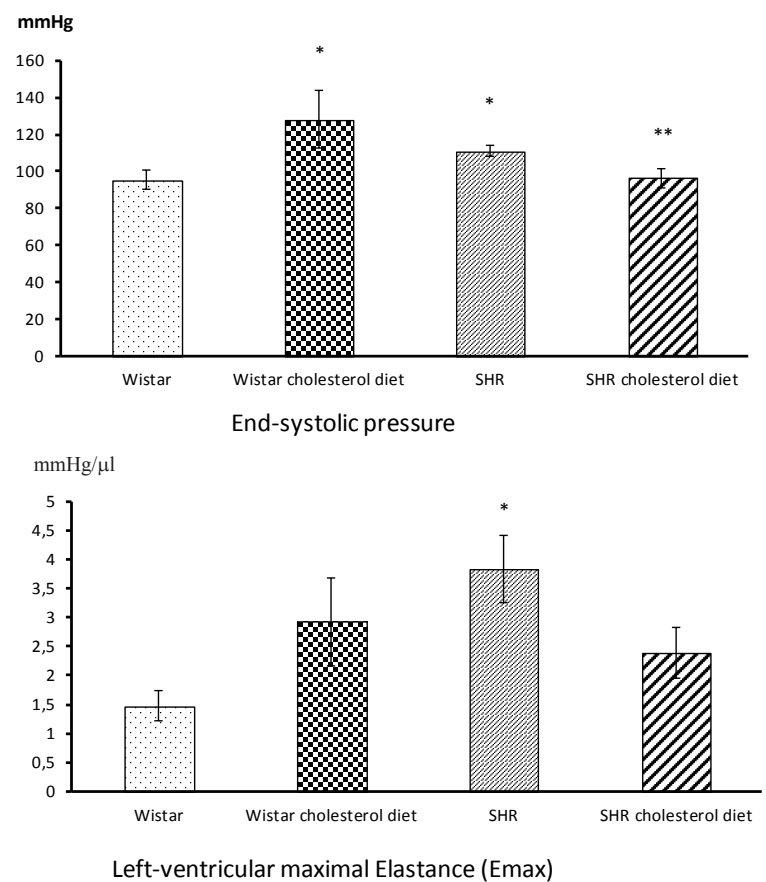

Fig.3. Effect of cholesterol diet (3\%) on end-systolic pressure and end-systolic left ventricular maximum volume elasticity (Emax) of Wistar and SHR rats.

* statistically significant difference comparing to Wistar rats on standard diet $(\mathrm{P}<0.05)$

** statistically significant difference comparing to SHR on standard diet $(\mathrm{P}<0.05)$ 
sure change (30\% increase) (Fig. 3, Table).

Diastolic ability of the heart of Wistar rats on cholesterol versus standard diet was evaluated by the next indices: end-diastolic volume (27\% decrease), end-diastolic pressure $(93 \%$ increase), isovolumic left ventricular relaxation time constant Tau evaluated by Weiss $(23 \%$ increase) method, minimal speed of pressure change $\mathrm{dP} / \mathrm{dt} \min (28 \%$ decrease), minimal speed of volume change $\mathrm{dV} / \mathrm{dt} \min (15 \%$ decrease) (Table). Same set of indices was evaluated in SHR rats on cholesterol versus standard diet difference: end-diastolic volume $(33 \%$ increase), end-diastolic pressure ( $8 \%$ decrease), isovolumic left ventricular relaxation time constant Tau evaluated by Weiss (6\% increase) and Glantz ( $2 \%$ increase) methods, minimal speed of pressure change $\mathrm{dP} / \mathrm{dt} \min (6 \%$ decrease), minimal speed of volume change $\mathrm{dV} / \mathrm{dt}$ min (93\% increase) (Table).

Another significant index in the course of our experiment was arterial elastance, which was 2.3 times increased in Wistar rats with cholesterol-rich comparing to standard diet. But in SHR groups cholesterol-rich diet results in $47 \%$ decrease of arterial elastance (Fig.4., Table).

\section{Blood lipid profile}

In the experimental groups, cholesterol-rich diet effect was quite predictable, and the worsening of blood lipids was well expected. But, what was not so obvious, that spontaneously hypertensive rats were more tolerant to cholesterol diet than Wistar rats comparing to their respective groups on standard diet.

Blood lipid profile in Wistar rats on cholesterol-rich diet was different from those on standard diet: total cholesterol ( $84 \%$ increase), cholesterol of high-density lipoproteins (26\% increase) and low density lipoproteins (more than 6 times increase) (Fig.5.). Same indices in SHR rats with cholesterol-rich diet were also different comparing to standard diet fed SHR: total cholesterol ( $81 \%$ increase), cholesterol of high-density lipoproteins (37\% increase) and low density lipoproteins (3.9 times increase) (Fig.5.). There were no statistically significant differences in triglycerides, cholesterol of very low-density lipoproteins levels and atherogenic index between all groups. Though comparing mean levels it can be pointed that SHR triglycerides (SHRs were 34\% higher than Wistar rats on standard diet, and $25 \%$ - on cholesterol-rich diet) were higher comparing to Wistar rats and there were little to no effect on cholesterol-rich diet on this parameters.

Thus, acquired data signified that cholesterol-rich diet induced shift of blood lipid fraction in both SHR and Wistar rats. The data may evidence that SHR rats were less susceptible to negative effects of cholesterol-rich diet on blood lipid levels, as their LDL levels after cholesterol-rich diet were significantly lower while HDL kept almost at the same concentra-

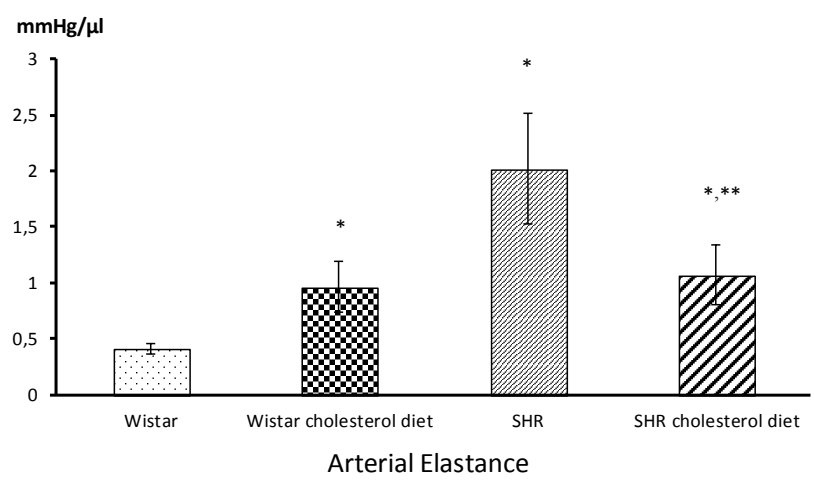

Fig.4. Effect of cholesterol diet (3\%) on Arterial Elastance of Wistar and SHR rats.

* statistically significant difference comparing to Wistar rats on standard $\operatorname{diet}(\mathrm{P}<0.05)$

** statistically significant difference comparing to SHR on standard $\operatorname{diet}(\mathrm{P}<0.05)$ 
tion comparing to Wistar rats. These two parameters are important for the known index of atherogenesis development probability, and in Wistar rats with cholesterol-rich diet atherogenic index was higher (22\% increase) then in respective SHR group. But we believe that in case of complex pathological process where there is the combined influence of several pathological factors (hypertension and high cholesterol diet) the meaning of this index could be not so much straightforward and histological researches must be conducted before any viable statement can be concluded. Nevertheless such differences in lipid profile are an effect of some changes in
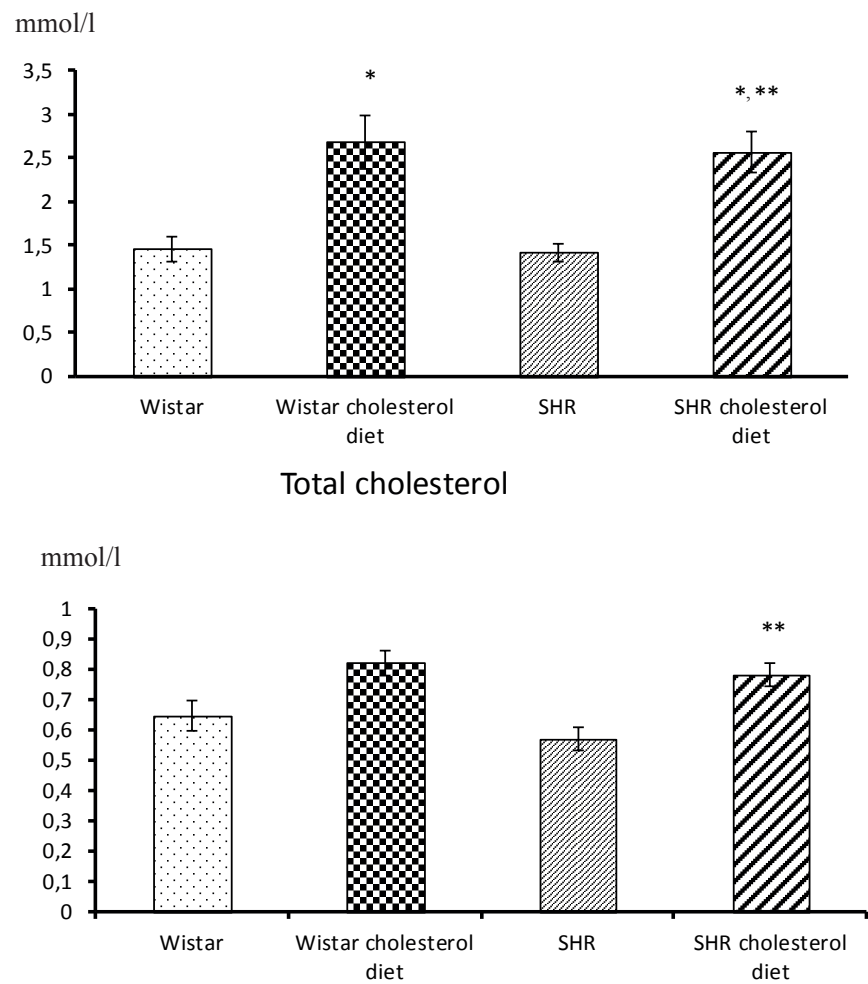

High density lipoproteins

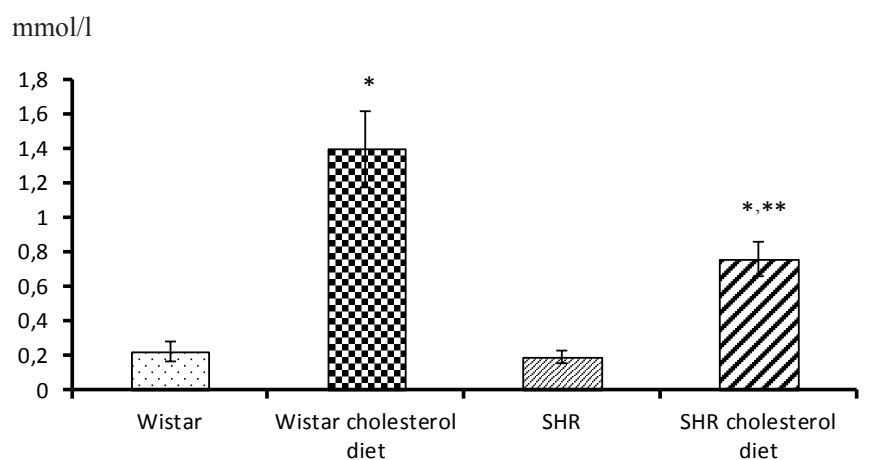

Low density lipoproteins

Fig.5. Effect of cholesterol diet (3\%) on blood total cholesterol, cholesterol of high-density and low density lipoproteins in Wistar and SHR rats.

* statistically significant difference comparing to Wistar rats on standard $\operatorname{diet}(\mathrm{P}<0.05)$

** statistically significant difference comparing to SHR on standard diet $(\mathrm{P}<0.05)$ 
SHR rats due to their hypertensive status [11, 12]. Such changes can be connected to understanding of how the excess amounts of lipids can be utilized. And the difference may be the result of some unconventional mechanisms activation in SHR, causing steatosis for example.

Also we can say that, paradoxically, cholesterol-rich diet affects hemodynamic function of Wistar rats and SHR differently, by worsening the state of the first one and by substantially improving the latter. Explanation to these unexpected results in our opinion is mainly associated with drastically improved Arterial Elastance in SHR rats, lowering afterload this way and then naturally followed by improvement of heart functions. This parameter can be connected to the blood vessels state, and taking into account the shift of blood lipid profile, we can assume the development of cholesterol-induced changes in arterial wall of SHR rats.

Thus, according to data acquired we can conclude that cholesterol-rich diet improved cardiac function parameters, in particular Arterial Elastance, in SHR comparing to Wistar rats. Also, SHRs were more resistant to deleterious effects of cholesterol-rich diet on their LDL level in blood.

The authors of this study confirm that the research and publication of the results were not associated with any conflicts regarding commercial or financial relations, relations with organizations and/or individuals who may have been related to the study, and interrelations of coauthors of the article.

\section{Г.В. Портніченко, С.В. Гончаров, Д.О. Строй, В.Є. Досенко \\ ПОКРАЩЕННЯ ГЕМОДИНАМІЧНИХ ПОКАЗНИКІВ У ЩУРІВ ЗІ СПОНТАННОЮ ГІПЕРТЕНЗІЄЮ ПІД ВПЛИВОМ ХОЛЕСТЕРИНОВОЇ ДІЄТИ}

Метою цієї роботи є визначення ефектів холестеринової дієти на всі основні гемодинамічні параметри та ліпідний метаболізм у щурів з гіпертензією. Експеримент проводили на щурах лінії Вістар та зі спонтанною гіпертензією. Тварини перебували на збагаченій холестерином (3\%,
«Sigma»,США) стандартній для гризунів дієті протягом 8 тиж. Показники кардіогемодинаміки вимірювали in vivo за допомогою чутливих до тиску й об'єму мікрокатетерів 2F (“Millar Instruments”,США), що вводили в порожнину лівого шлуночка. Холестеринові фракції крові визначали біохімічно. Отримані результати, парадоксально, свідчать про покращення під дією холестеринової дієти основних параметрів функції серця щурів з гіпертензією, зокрема: фракції викиду (збільшилась на $31 \%$ ), ударного об’єму (збільшився на 72\%), хвилинного об'єму серця (збільшився на 69\%) тощо. Водночас щури з гіпертензією були більш стійкими до змін у складі холестеринових фракцій крові, зокрема однаковий з щурами лінії Вістар вміст ЛПВЩ, але на 46\% нижчий ЛПНЩ. Таким чином, хронічна артеріальна гіпертензія знижує чутливість щурів до екзогенного холестерину. Спільний вплив холестерину та гіпертензії здійснює протективну дію на функцію серця порівняно зі щурами з нормальним тиском.

Ключові слова: гіпертензія; ліпідний метаболізм; холестеринова дієта; кардіогемодинаміка; щури 3 гіпертензією.

Інститут фізіології ім. О.О. Богомольия НАН Украӥни; Kuїв;

e-mail: krissaegrim1@gmail.com

\section{Г.В. Портниченко, С.В. Гончаров, Д.О. Строй, В.Е. Досенко \\ УЛУЧШЕНИЕ ГЕМОДИНАМИЧЕСКИХ ПОКАЗАТЕЛЕЙ У КРЫС СО СПОНТАН- НОЙ ГИПЕРТЕНЗИЕЙ ПОД ДЕЙСТВИЕМ ХОЛЕСТЕРИНОВОЙ ДИЕТЫ}

Целью этой работы является определение эффектов холестериновой диеты на все основные гемодинамические показатели и липидный метаболизм у спонтанногипертензивных крыс. Эксперименты проводились на 6-месячных самцах крыс линии Вистар и со спонтанной гипертензией. Животные находились на обогащенной холестерином (3\%) стандартной диете грызунов на протяжении 8 нед. Показатели кардиогемодинамики измеряли in vivo с помощью чувствительных к давлению и объёму микрокатетерова 2F ("Millar Instruments", США), которые вводили в полость левого желудочка. Холестериновые фракции крови определялись биохимически. Полученные результаты, парадоксально, свидетельствуют об улучшении под действием холестериновой диеты параметров функции сердца крыс с гипертензией, в частности: фракции выброса (увеличилась на $31 \%$ ), ударного объёма (увеличился на $72 \%$ ), минутного объёма сердца (увеличился на 69\%) и т.д. В то же время крысы с гипертензией были более стойкими к изменениям в составе холестериновых фракций крови, в частности одинаковое с крысами линии Вистар содержание ЛПВП, но на 46\% более низкое ЛПВП. Таким образом, артериальная гипертензия уменьшала чувствительность 
крыс к экзогенному холестерину. Совместное влияние холестерина и гипертензии оказывало протективное действие на функцию сердца в сравнении с крысами с нормальным давлением.

Ключевые слова: гипертензия; липидный метаболизм; холестериновая диета; кардиогемодинамика; крысы со спонтанной гипертензией.

\section{REFERENCES}

1. Stephen C. Kolwicz Jr. An "Exercise" in Cardiac Metabolism. Front Cardiovasc Med. 2018; 5: 66.

2. Shimano H. SREBPs: physiology and pathophysiology of the SREBP family. FEBS J. 2009 Feb;276(3):616-21.

3. Wende AR, Abel ED. Lipotoxicity in the heart. Biochim Biophys Acta. 2010 Mar;1801(3):311-9.

4. Sato R. Sterol metabolism and SREBP activation. Arch Biochem Biophys. 2010 Sep 15;501(2):177-81.

5. Lee H, Yoo YS, Lee D, Song EJ. Cholesterol induces cardiac hypertrophy by activating the AKT pathway. J Steroid Biochem Mol Biol. 2013 Nov;138:307-13.

6. Portnichenko AG, Lapikova-Briginskaia TIu, Vasilenko MI, Portnichenko GV, Maslov LN, Moíbenko AA. The expression of Akt kinase in the heart ventricles under hypoxic preconditioning and myocardial remodeling.
Fiziol Zh. 2013;59(6):124-31. [Ukrainian].

7. Aidietis A1, Laucevicius A, Marinskis G. Hypertension and cardiac arrhythmias. Curr Pharm Des. 2007;13(25):2545-55.

8. Park HJ, Georgescu SP, Du C, Madias C, Aronovitz MJ, Welzig CM, et al. Parasympathetic response in chick myocytes and mouse heart is controlled by SREBP. J Clin Invest. 2008 Jan;118(1):259-71.

9. Jing Xiao, Tianqi Hua, Huan Shen, Min Zhang, XiaoJian Wang, Yue-Xia Gao, Qinyun Lu \& Chuanli Wu Associations of metabolic disorder factors with the risk of uncontrolled hypertension: a follow-up cohort in rural China. Sci Rep. 2017; 7: 743.

10. Pacher P, Nagayama T, Mukhopadhyay P, Bátkai S, Kass DA. Measurement of cardiac function using pressurevolume conductance catheter technique in mice and rats. Nat Protoc. 2008;3(9):1422-34.

11. Anonymous. National Education Programs Working Group report on the management of patients with hypertension and high blood cholesterol. Ann Intern Med 1991; 114: 224-37.

12. Meigs JB, D’Agostino RB Sr, Wilson PW, Cupples LA, Nathan DM, Singer DE. Risk variable clustering in the insulin resistance syndrome. The Framingham Offspring Study. Diabetes. 1997 Oct;46(10):1594-600. 